\title{
Synthesis of $\boldsymbol{R}$-(+)-limonene thiosemicarbazones using silica supported acid under solvent-free conditions and synthesis of its 1,3,4-thiadiazoles derivates
}

\author{
Fábio Vandresen ${ }^{1}$, Rafael C. Mantovan¹, Cecília M.A. de Oliveira², Cleuza C. da \\ Silva ${ }^{1^{*}}$. \\ ${ }^{1}$ Departamento de Química, Universidade Estadual de Maringá, Av. Colombo, 5790, 87020-900,Maringá- \\ PR. ${ }^{2}$ Universidade Federal de Goiás - Instituto de Química - Campus II - 74091-970 - Goiânia-GO. \\ *ccsilva@uem.br
}

Keywords: thiosemicarbazones, 1,3,4-thiadiazoles, $R$-(+)-limonene.

\section{INTRODUCTION}

Thiosemicarbazones and 1,3,4-thiadiazoles have been reported to exhibit a wide range of biological effects among which are antitumor, antiprotozoal, and antimicrobial activities. ${ }^{1-3}$ The majority of the active thiosemicarbazones present the simplest aryl or alkyl groups at the $N-4$ and the more diverse $\mathrm{R} 1$ and $\mathrm{R} 2$ groups on the carbon at the imine moiety. Recently, our group has synthesized new thiosemicarbazones endowed with a bisabolol group on $N-4$ position which showed relevant antitumor activity ${ }^{4}$. Herein, we report new thiosemicarbazones bearing a $\mathrm{R}-(+)$-limonene moiety at the $\mathrm{N}-4$ that were synthesized using silica supported acid under solvent-free conditions. Also, the synthesis of its 1,3,4-thiadiazoles derivatives is described.

\section{RESULTS AND DISCUSSION}

The synthesis of the R-(+)-limonene thiosemicarbazones (3-26) and 1,3,4-thiadiazoles (27-38) was achieved according to the reaction sequence shown in Scheme 1. The condensation of thiosemicarbazide (2) with different carbonyl compounds (aldehydes and ketones) was first performed following the normal procedure at reflux in $\mathrm{EtOH}$ using a catalytic amount of acid (M1). In the effort to improve the yield of the thiosemicarbazones it was decided to attempt the condensation reaction according to the procedure ${ }^{5}$ that uses silica gel catalyzed with $\mathrm{H}_{2} \mathrm{SO}_{4}$ under solvent-free conditions (M2). Thus, the carbonyl compound and tiossemicarbazide (2) were stirred with a mixture of silica gel: $\mathrm{H}_{2} \mathrm{SO}_{4} 5 \%$ at room temperature or under microwave irradiation, for 520 min., to give the compounds (3-26) in good yields (65-97\%). Purification procedures were not needed.

The 1,3,4-thiadiazoles (27-38) derivatives were obtained in satisfactory yield (35-85\%) by oxidative cyclization with ferric chloride of the benzaldehyde derivatives of thiosemicarbazones (3-14). ${ }^{6}$

All compounds were characterized by spectrometric data (NMR, IR, MS). In Table 1, the yields for both methods are displayed.
Scheme 1. Synthetic route to thiosemicarbazones and 1,3,4-thiadiazoles.

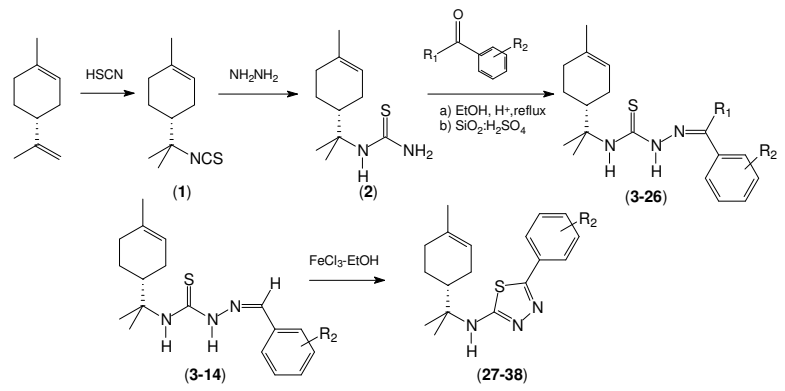

Table 1. Yields obtained to thiosemicarbazones.

\begin{tabular}{|c|c|c|c|c|c|c|c|c|c|}
\hline & $\overline{\mathbf{R}_{1}}$ & $\overline{\mathbf{R}_{2}}$ & R\%(M1) & R\%(M2) & & $\overline{\mathbf{R}_{1}}$ & $\mathbf{R}_{2}$ & R\%(M1) & R\%(M2) \\
\hline 3 & $\mathrm{H}$ & $\mathrm{H}$ & 70 & 88 & 15 & $\mathrm{H}$ & $2-\mathrm{OH}$ & 67 & 65 \\
\hline 4 & $\mathrm{H}$ & 4- $-\mathrm{CH}_{3}$ & 76 & 90 & 16 & $\mathrm{H}$ & $3-\mathrm{OCH}_{3}, 4-\mathrm{OH}$ & 57 & 80 \\
\hline 5 & $\mathrm{H}$ & $4-\mathrm{OCH}_{3}$ & 80 & 85 & 17 & $\mathrm{CH}_{3}$ & $\mathrm{H}$ & 55 & $86^{*}$ \\
\hline 6 & $\mathrm{H}$ & $4-\mathrm{OH}$ & 35 & 74 & 18 & $\mathrm{CH}_{3}$ & 4- $-\mathrm{CH}_{3}$ & 66 & $87^{*}$ \\
\hline 7 & $\mathrm{H}$ & $4-\mathrm{N}_{\left(\mathrm{CH}_{3}\right)_{2}}$ & 41 & 76 & 19 & $\mathrm{CH}_{3}$ & $4-\mathrm{OCH}_{3}$ & 80 & $88^{*}$ \\
\hline 8 & $\mathrm{H}$ & $2-\mathrm{Cl}$ & 69 & 92 & 20 & $\mathrm{CH}_{3}$ & $4-\mathrm{OH}$ & 35 & $65^{*}$ \\
\hline 9 & $\mathrm{H}$ & $3-\mathrm{Cl}$ & 70 & 88 & 21 & $\mathrm{CH}_{3}$ & $4-\mathrm{F}$ & 60 & $90^{*}$ \\
\hline 10 & $\mathrm{H}$ & $4-\mathrm{Cl}$ & 81 & 83 & 22 & $\mathrm{CH}_{3}$ & $4-\mathrm{Cl}$ & 57 & $91^{*}$ \\
\hline 11 & $\mathrm{H}$ & $2-\mathrm{NO}_{2}$ & 76 & 94 & 23 & $\mathrm{CH}_{3}$ & $4-\mathrm{NO}_{2}$ & 85 & $94^{*}$ \\
\hline 12 & $\mathrm{H}$ & 3- $\mathrm{NO}_{2}$ & 75 & 97 & 24 & $\mathrm{C}_{6} \mathrm{H}_{5}$ & $\mathrm{H}$ & 60 & $65^{*}$ \\
\hline 13 & $\mathrm{H}$ & $4-\mathrm{NO}_{2}$ & 85 & 97 & 25 & $\mathrm{CH}_{3}$ & $\mathrm{CH}_{3}$ & 46 & $66^{*}$ \\
\hline 14 & $\mathrm{H}$ & $4-\mathrm{F}$ & 80 & 96 & 26 & $\mathrm{CH}_{3} \mathrm{CH}_{2}$ & $\mathrm{CH}_{3}\left(\mathrm{CH}_{2}\right)_{3}$ & 35 & $85^{*}$ \\
\hline
\end{tabular}

M1- method (EtOH, $\left.\mathrm{H}^{+} / 1-26 \mathrm{hs}\right)$; $\mathrm{M} 2-\left(\mathrm{SiO}_{2}-\mathrm{H}_{2} \mathrm{SO}_{4} / 5-20\right.$ min.; ${ }^{*}$ using microwave).

CONCLUSION

This study employed a fast

and

efficient methodology for thiosemicarbazones synthesis, which suits the requirements of green chemistry. A comparative study of reaction time and yields obtained by this technique was also possible with the conventional methods, highlighting its capability to access the formation of the products in short time reaction with better yields.

\section{ACKNOWLEDGEMENTS}

UEM-DQI, UFG-IQ, CNPq, Fundação Araucária

\section{REFERENCES}

1 Thanigaimalai, P.et al. Biorg.Med.Chem. Lett. 2010, 20, 2991.

${ }^{2}$ Dodd, R.H., et al. J.Med.Chem. 1989, 32, 1272.

${ }^{3}$ Bal, T.R., et al. Biorg.Med.Chem. Lett. 2005, 15, 4451.

${ }^{4}$ Silva, A.P. et al. Eur. J.Med. Chem. 2010, 45, 2987.

${ }^{5}$ Chen, X. et al. Synthetic Comm. 2009, 39, 947.

${ }^{6}$ Shih, M.; Wu, C. Tetrahedron, 2005, 61,1091. 